\title{
Homozygous Hypobetalipoproteinemia: a Disease Distinct from Abetalipoproproteinemia at the Molecular Level
}

\author{
Robert S. Ross," Richard E. Gregg," Simon W. Law," Juan Carlos Monge," Stephen M. Grant, ${ }^{\star}$ Keiichi Higuchi, \\ Timothy J. Triche, ${ }^{\ddagger}$ Jane Jefferson, ${ }^{\ddagger}$ and H. Bryan Brewer, Jr.* \\ *Molecular Disease Branch, National Heart, Lung and Blood Institute, and ${ }^{\ddagger}$ Laboratory of Pathology, \\ National Cancer Institute, National Institutes of Health, Bethesda, Maryland 20892
}

\begin{abstract}
apoB DNA, RNA, and protein from two patients with homozygous hypobetalipoproteinemia (HBL) were evaluated and compared with normal individuals. Southern blot analysis with 10 different cDNA probes revealed a normal gene without major insertions, deletions, or rearrangements. Northern and slot blot analyses of total liver mRNA from HBL patients documented a normal size apoB mRNA that was present in greatly reduced quantities. ApoB protein was detected within HBL hepatocytes utilizing immunohistochemical techniques; however, it was markedly reduced in quantity when compared with control samples. No apoB was detectable in the plasma of HBL individuals with an ELISA assay. These data are most consistent with a mutation in the coding portion of the apoB gene in $\mathrm{HBL}$ patients, leading to an abnormal apoB protein and apoB mRNA instability. These results are distinct from those previously noted in abetalipoproteinemia, which was characterized by an elevated level of hepatic apoB mRNA and accumulation of intracellular hepatic apoB protein.
\end{abstract}

\section{Introduction}

Homozygous familial hypobetalipoproteinemia (HBL) ${ }^{1}$ is a rare disease characterized by low plasma concentrations of cholesterol and triglycerides and a virtual absence of apoB as well as the apoB-containing lipoproteins including chylomicrons, VLDL, IDL, and LDL. HBL has been proposed to be due to a defect in synthesis and secretion of triglyceride-rich apoB-100 and apoB-48 containing lipoprotein particles by the liver and intestine (1).

Clinically, the homozygous form of this disease presents with early and late complications secondary to the absence of apoB-containing lipoproteins. Acanthocytosis and fat malabsorption may be exhibited from birth $(1,2)$. Acanthocytosis is associated with an abnormally low sphingomyelin to phosphatidylcholine ratio in the red cell (1), while the fat malab-

Address correspondence to Dr. Ross, National Institues of Health, Bldg. 10, Room 7N117, Bethesda, MD 20892.

Received for publication 1 June 1987 and in revised form 15 September 1987.

1. Abbreviations used in this paper: $\mathrm{ABL}$, abetalipoproteinemia; HBL, hypobetalipoproteinemia; TBS, Tris-buffered saline.

The Journal of Clinical Investigation, Inc.

Volume 81, February 1988, 590-595 sorption results from the inability of enterocytes to synthesize and secrete triglyceride-rich chylomicrons (2). The late sequelae are secondary to malabsorption of fat soluble vitamins (3). Of particular importance are retinitis pigmentosa and neurological findings similar to Friedrich's ataxia. The neurologic and retinal diseases are likely to be secondary to prolonged vitamin $\mathrm{E}$ deficiency as the development or progression of these symptoms may be retarded by vitamin E supplementation (4). Vitamin $\mathrm{K}$ deficiency can result in clotting abnormalities $(5,6)$. Typical manifestations of vitamin A or D deficiency are rarely observed in these patients $(1,3)$.

The present studies were undertaken to evaluate the molecular defect in homozygous HBL, and compare it with our previous findings reported in abetalipoproteinemia (ABL) (7).

\section{Methods}

Experimental subjects. Two patients with HBL were evaluated. Patient 1 is a 54-yr-old woman who has been reported previously (6). Patient 2 , a 47-yr-old caucasian female, has acanthocytosis, subtle pigmentary changes consistent with retinitis pigmentosa, and a mild sensory polyneuropathy with a resultant sensory ataxia. Lipoprotein analyses were performed in the proband as well as other obligate heterozygotes in the kindred. The subject's lipoprotein values included a total cholesterol of $30 \mathrm{mg} / \mathrm{dl}$, triglycerides $<4 \mathrm{mg} / \mathrm{dl}$, VLDL cholesterol of $2 \mathrm{mg} / \mathrm{dl}$, LDL cholesterol that was undetectable, and an HDL cholesterol of 30 $\mathrm{mg} / \mathrm{dl}$. The LDL cholesterol values for her father, daughter, and two sons were $37,43,22$, and $12 \mathrm{mg} / \mathrm{dl}$, respectively. On the basis of these results, patient 2 was diagnosed as having homozygous HBL. Informed consent was obtained for all studies performed with these patients.

Plasma apoB level. Fresh whole blood samples were collected in $0.1 \%$ EDTA from both patients with homozygous HBL. Plasma was separated via centrifugation and apoB was analyzed by an ELISA assay. ApoB was undetectable $(<0.05 \mathrm{mg} / \mathrm{dl})$ in both patients. Normal values for apoB in our laboratory are $89 \pm 19 \mathrm{mg} / \mathrm{dl}(8)$.

$R N A$ preparation. Liver tissue was obtained from HBL patients via percutaneous needle biopsy and from normal patients at the time of organ donation. Tissue was stored at $-70^{\circ} \mathrm{C}$ until used. RNA was isolated utilizing the guanidine thiocyanate procedure as reported previously $(7,9)$.

DNA preparation. Leukocyte DNA was isolated from whole blood of normal and HBL subjects as previously described (10).

cDNA probes. Double-stranded cDNA probes were prepared from apoB-100 cDNA clones. Nine clones were derived from ones previously described by our laboratory (11). Additionally a tenth apoB-100 clone, 959 bp in length, was kindly supplied by A. A. Protter (California Biotechnology Corp., Mountain View, CA) (12). A human serum albumin cDNA clone isolated from a cDNA library (13) and an 850-bp MSP I restriction digest of an apoA-I cDNA clone (14) were also used as positive controls for the evaluation of apoB-100 mRNA. Probes were nick translated with $\left[\alpha^{32} \mathrm{P}\right] \mathrm{dCTP}$ to a specific activity of $\sim 1 \times 10^{8} \mathrm{dpm} / \mu \mathrm{g}$. 
Northern and slot blot hybridization analyses of RNA. Gels for Northern blot analysis were prepared with $1 \%$ agarose in the presence of $6 \%$ formaldehyde, electrophoresed at $25 \mathrm{~V}$ for $16 \mathrm{~h}$, and transferred to nitrocellulose filters (Schleicher and Schuell, Inc., Keene, NH) as described previously (15). Each sample analysis used $10 \mu \mathrm{g}$ of total mRNA. Gels were stained with ethidium bromide to confirm that equivalent quantities of RNA were loaded in each lane.

For slot blot analysis, serial dilutions of total RNA (7.5, 5.0, 2.5, and $1.0 \mu \mathrm{g}$ ) were loaded in triplicate onto a nylon filter (Nytran; Scheilcher and Schuller, Inc.) using a slot blot apparatus (Bethesda Research Laboratories, Gaithersburg, MD). Filters were baked for $2 \mathrm{~h}$ at $80^{\circ} \mathrm{C}$ and then prehybridized in $5 \times$ standard saline citrate (SSC) $(1 \times$ $\mathrm{SSC}=150 \mathrm{mM} \mathrm{NaCl}, 15 \mathrm{mM} \mathrm{Na}$ citrate, $\mathrm{pH} 7.0$ ), $5 \times$ Denhardt's solution $(0.1 \%$ ficoll, $0.1 \%$ polyvinylpyrrolidone, $0.1 \% \mathrm{BSA}), 0.1 \%$ SDS, $10 \mathrm{mM}$ Tris- $\mathrm{HCl}$ (pH 7.4), 50\% formamide, and $100 \mu \mathrm{g} / \mathrm{ml}$ sonicated herring sperm DNA for $4-16 \mathrm{~h}$ at $42^{\circ} \mathrm{C}$. Hybridization was performed for $48 \mathrm{~h}$ at $42^{\circ} \mathrm{C}$ in the same solution as noted above for prehybridization except that the herring sperm DNA was replaced by a nick translated cDNA probe at $1-2 \times 10^{7} \mathrm{dpm} /$ filter. Posthybridization washes were carried out twice, briefly, with $2 \times$ SSC at room temperature followed by incubation at $65^{\circ} \mathrm{C}$ for $30 \mathrm{~min}$ each in $2 \times$ SSC $/ 0.1 \%$ SDS, followed by $1 \times$ SSC $/ 0.1 \%$ SDS. Filters were autoradigraphed and scanned using a laser densitomer (Ultrascan XL; LKB Instruments, Bromma, Sweden). The absorbancy values were normalized with the normal RNA being assigned a value of 1 . For reuse, filters were stripped of radiolabeled probe by incubation in $0.1 \times \mathrm{SSC} / 0.1 \%$ SDS at $90^{\circ} \mathrm{C}$ for $1 \mathrm{~h}$.

Southern blot analysis. Leukocyte DNA $(10 \mu \mathrm{g})$ was cleaved with restriction endonucleases $(3 \mathrm{U} / \mu \mathrm{g})$ at $37^{\circ} \mathrm{C}$ for $4-6 \mathrm{~h}$ in reaction buffers provided by the suppliers (Bethesda Research Laboratories, Boehringer Mannheim Biochemicals, Indianapolis, IN, and New England Biolabs, Beverly, MA). Fragments were separated in $0.7 \%$ agarose gels electrophoresed at $25 \mathrm{~V}$ for $16 \mathrm{~h}$. After electrophoresis the gels were incubated in $0.2 \mathrm{~N} \mathrm{HCl}$ for $10 \mathrm{~min}$, followed by $30 \mathrm{~min}$ each in $0.5 \mathrm{~N} \mathrm{NaOH} / 0.6 \mathrm{M} \mathrm{NaCl}$ and $1.5 \mathrm{M} \mathrm{NaCl} / 0.5 \mathrm{M}$ Tris- $\mathrm{HCl}$ (pH 7.4) at room temperature. DNA was transferred to a nylon support (Zetabind; AMF/CUNO, Meriden, CT) (16). Baking, prehybridization, hybridization, and stripping were all performed as outlined above for RNA analysis.

Immunocytochemistry. Frozen sections (10 $\mu \mathrm{m}$ thick) were prepared from liver biopsies of normal and HBL individuals, embedded in OCT compound, air dried, and stored at $-80^{\circ} \mathrm{C}$ until use. Specimens

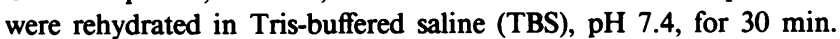
Slides were pretreated with $10 \%$ egg albumin (to block nonspecific antibody binding), rinsed three times in TBS, and incubated overnight at $4^{\circ} \mathrm{C}$ with the primary antibody. This included either a mixture of mouse monoclonal human anti-apoB antibodies (ABB1, ABB2, ABB3, ABB5 [1:1:1:1]; Canadian Bioclinical, Ltd., Scarborough, Ontario, Canada) used at 1:1,000 dilution, an irrelevant monoclonal antibody derived from a neuroblastoma (HSAN 1.2, a gift of C. Patrick Reynolds, Naval Medical Research Institute, Bethesda, MD), or nonimmune mouse ascites fluid (Collaborative Research, Inc., Warrensburg, PA). All primary incubations were performed at protein concentrations comparable with the ABB mixture. After the primary incubation, unbound antibody was removed with TBS/1\% albumin (three rinses) and the sections reincubated with a sheep anti-mouse second antibody. Bound second antibody was detected utilizing an alkaline phophastase-mouse anti-alkaline phosphatase antibody bridge technique (17) (Dako, Santa Barbara, CA). Endogenous alkaline phosphatase activity was inhibited by addition of $1 \mathrm{mM}$ levamisole to the enzyme substrate solution.

Statistics. All statistical methods were carried out using standard techniques (18).

\section{Results}

The unrelated patients evaluated in this report satisfied the diagnostic criteria for familial homozygous HBL. Both presented with symptoms secondary to fat malabsorption and/or associated fat soluble vitamin deficiency. Pigmentary changes consistent with retinitis pigmentosa and neurologic abnormalities were noted in both probands. Reduced plasma cholesterol and triglyceride levels, virtual absence of chylomicrons, VLDL, IDL, and LDL, as well as undetectable plasma apoB $(<0.05 \mathrm{mg} / \mathrm{dl})$, were consistent with homozygous $\mathrm{HBL}$, while half normal levels of LDL in the obligate heterozygotes confirmed the diagnosis.

Southern blot analysis comparing the apoB gene from the two homozygous HBL patients and two normal individuals was performed using $10 \mathrm{cDNA}$ probes spanning the full $43-\mathrm{kb}$ apoB gene (19). The DNA was cleaved with restriction enzymes including Bgl II, Eco RI, Hind III, and Pvu II, and the location of the individual restriction sites are illustrated in Fig. 1. All restriction endonuclease fragment sizes were indistinguishable between control and homozygous HBL patients. Representative Southern blots are illustrated in Fig. 2, $A$ and $B$. Comparison of these restriction fragments with a previously published restriction map of the apoB-100 gene (19) revealed several additional cleavage sites. These include a Hind III site within the $3^{\prime}$ portion of exon 26 as well as Pvu II sites within exons 10 and 20 , and introns 4,16 , and 18.

Northern tlot analysis of total liver RNA revealed apoB-100 mRNA in HBL subjects to be of normal size, but greatly reduced in quantity when compared with RNA from normal patients (Fig. $3 \mathrm{~A}$ ). Ethidium bromide staining of the gel confirmed that equivalent amounts of nucleic acid had been loaded in all sample lanes (data not shown). Stripping and rehybridization of the blot illustrated in Fig. $3 \mathrm{~A}$, with nick translated apoA-I and HSA cDNA probes followed by autoradiography, revealed that nearly equal levels of both of these mRNAs were present in hepatocytes from both HBL and normal subjects (Fig. 3, $B$ and $C$ ). This confirmed that the decreased mRNA in the homozygous HBL patients was specific for apoB mRNA. To quantitate the decrease in apoB mRNA in HBL individuals, quantitative slot blot hybridization was performed with total liver RNA. Triplicate samples of four different quantities of RNA were analyzed for each subject. Filters were hybridized with two separate apoB cDNA probes (B14-16 and B29, located in the $5^{\prime}$ and $3^{\prime}$ regions of the apoB gene, respectively. Similar results were obtained with both probes. As is illustrated in Fig. 4, hepatic apoB mRNA from HBL subjects was reduced to $8-14 \%$ of the mRNA present in control subjects. The levels of HSA and apoA-I mRNAs were similar in both normal and HBL subjects, confirming the results obtained with Northern blot analysis.

Immunohistochemistry was performed using a pool of four monoclonal antibodies to apoB, two specific for the $\mathrm{NH}_{2}$-terminal end of the molecule, and two for the $\mathrm{COOH}$-terminal end. Hepatic tissue from both patients with homozygous HBL as well as normal controls were studied. Normal liver, when incubated with either the nonimmune (data not shown) or irrelevant monoclonal antibody (Fig. $5 \mathrm{~A}$ ), showed no reaction products. Blue-stained hepatocyte nuclei are visible and the cytoplasm is unstained. Occasional clusters of artifactually precipitated reaction product unassociated with any cellular elements were observed. When the apoB specific monoclonal antibody mixture was used as the primary antibody on normal liver, significant cytoplasmic staining of hepatocytes was noted (Fig. $5 \mathrm{~B}$ ). In addition, particularly dense reaction products were identified along hepatic sinusoids, indicative of the normally high concentration of apoB found in plasma. 

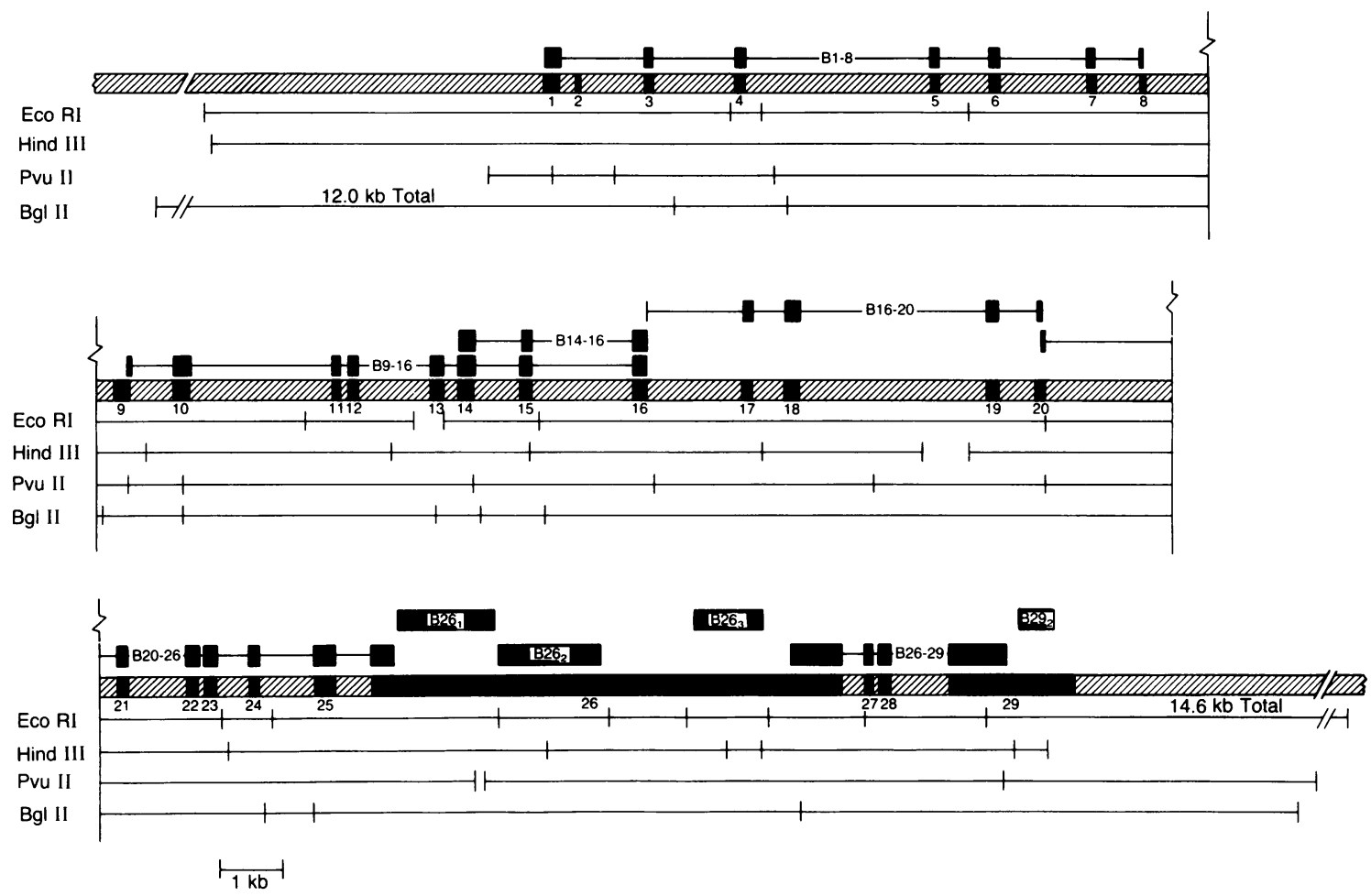

Figure 1. The gene mapping strategy used in the evaluation of the apoB gene in the HBL subjects. The upper lines in each row $(-)$ represent the lengths of the genomic DNA containing the exons coding for each of the cDNA probes utilized. The middle line ("enYN") represents the apoB gene with the exons and introns being indicated by the solid and cross-hatched regions, respectively. Both the probes and the exons are numbered sequentially from the $5^{\prime}$ to $3^{\prime}$ end. The last four lines of each row represent the restriction fragments generated by the indicated restriction endonucleases.

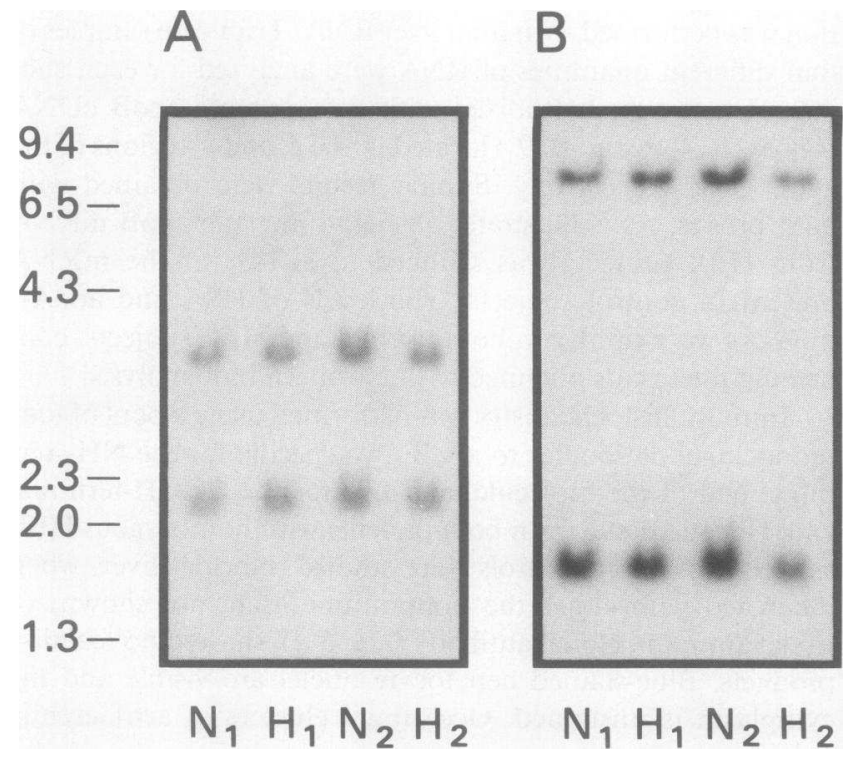

Figure 2. Representative Southern blots of leukocyte DNA from normal subjects (N) and homozygous HBL subjects (H). $A$ and $B$ contain Hind III and Eco RI restriction fragments, respectively. Clone B14-16 was used as the probe in both panels (see Fig. 1 for the location of the probe).

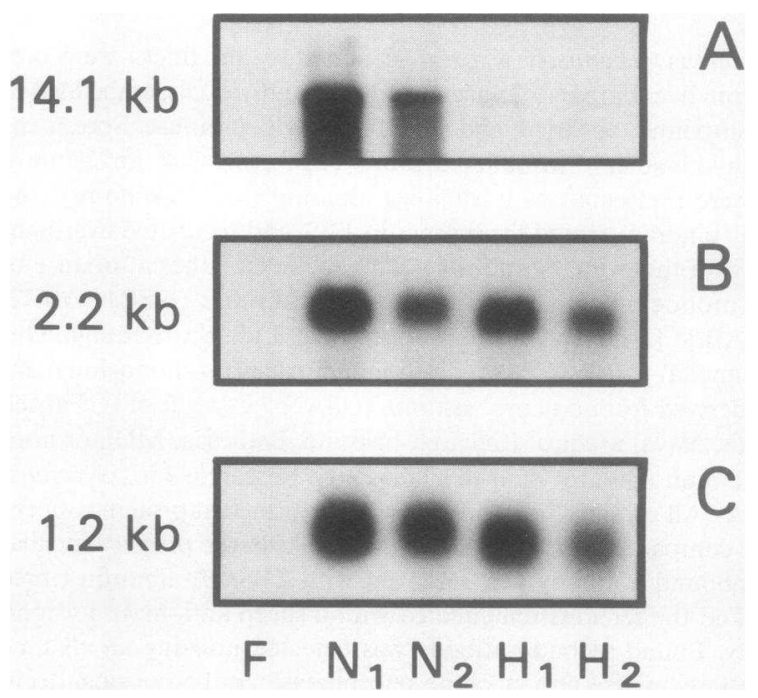

Figure 3. Northern blot analysis of $10 \mu \mathrm{g}$ of total liver RNA isolated from two normal subjects $(\mathrm{N})$, two homozygous HBL patients $(\mathrm{H})$, and a human fibroblast cell line (F). $A, B$, and $C$ contain blots hybridized with apoB cDNA probes B14-16, a HSA cDNA probe (13), and a human apoA-I cDNA probe (14), respectively. Molecular weight markers are indicated on the left in kilobases. Due to low levels of liver RNA, the 14.1-kb band is difficult to visualize in sample lanes $H_{1}$ and $H_{2}$. 


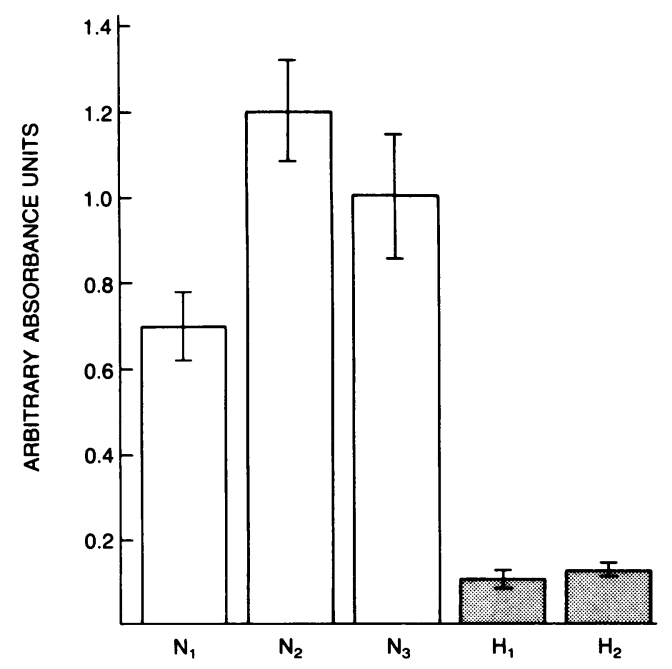

Figure 4. Quantitation of total hepatic apoB mRNA from three normal controls $(\mathrm{N})$, compared with two homozygous $\mathrm{HBL}$ patients $(\mathrm{H})$, by slot blot analysis. All values were normalized to the mean of the control values being equated to one. Error bars note standard deviation of the respective mean.

Liver specimens from HBL patients contained diffuse cytoplasmic staining of apoB protein; however, the intensity of the reaction was markedly decreased in comparison to normal hepatocytes, with patient 1 having slightly more staining than patient 2 (Fig. 5, $C$ and $D$, respectively). The magnitude of this reduction in immunoreactive apoB was qualitatively similar to the decrease in mRNA quantitated by slot blot analysis. Noteworthy is the absence of intense sinusoidal staining in both HBL patients, which is consistent with the undetectable levels of apoB in plasma.

\section{Discussion}

We have analyzed apoB DNA, RNA, and protein from patients with familial homozygous HBL. Southern blot analysis reveals a normal gene without major insertions or deletions; however, small insertions, deletions, or rearrangements may go undetected with this method. Northern and slot blot analyses established that the mRNA was of normal size, however greatly reduced in quantity. ApoB was detected intracellularly by immunohistochemistry, but at a reduced concentration. No apoB was detectable in the plasma with a very sensitive ELISA assay.

There are multiple possible molecular defects that could lead to a normal size mRNA present in greatly reduced amounts, as is present in homozygous HBL (20). First, there could be defects in the regulatory elements of the apoB gene resulting in a decreased transcriptional rate (21-23), or defects in the transcribed product that would result in inefficient splicing, nuclear processing, and transport to the cytoplasm $(24,25)$. Second, there could be a mutation in the transcribed product with the formation of an unstable mRNA. This may be caused by subtle defects in the $3^{\prime} \mathrm{AU}$ rich region (26), the polyadenylation site of the mRNA (27), or by an abnormality in the translated portion of the apoB mRNA resulting in both an abnormal translated product and an unstable mRNA (28).

Clinically, familial homozygous HBL is distinct from ho- mozygous ABL. The clinical manifestations of HBL patients are significantly milder than those of ABL patients and occur later in life. Symptoms in both groups of patients result from fat and fat soluble vitamin malabsorption. The pathophysiological basis for the presentation of symptoms in ABL patients at a younger age than HBL patients, is as yet unknown.

Biochemically, homozygous ABL and homozygous HBL result in the virtual absence of apoB in plasma. They are indistinguishable in the homozygous form by plasma apoB evaluation, and can only be clinically differentiated through plasma analysis of obligate heterozygotes. ABL heterozygotes have normal levels of apoB and apoB-containing lipoproteins, while HBL heterozygotes have half-normal plasma levels. ABL and HBL are therefore transmitted as autosomal recessive and autosomal co-dominant diseases, respectively.

Four general classes of molecular defects affecting apoB production could result in the characteristic biochemical absence of plasma B apolipoproteins. These include four classes of defects: (i) total absence of the apoB gene; (ii) transcriptional abnormalities of the apoB gene; (iii) translational abnormalities of the apoB mRNA; and (iv) secretory abnormalities caused by abberrant posttranslational processing of apoB or defects intrinsic to the apoB secretory pathway itself.

The results obtained in patients with homozygous HBL are quite distinct from those we have previously reported in ABL (19). Both groups of patients have virtually no detectable apoB in plasma. However, analysis by immunohistochemistry techniques revealed a normal to increased amount of hepatic apoB protein in ABL patients and a reduced quantity of apoB in HBL hepatocytes when compared with controls. Hepatic apoB mRNA was significantly increased in ABL but was reduced to $8-14 \%$ of control values in the HBL subjects. DNA from both HBL and ABL subjects contained no abnormality detectable by Southern blot analysis. We have proposed that the molecular defect in ABL is secondary to defective cellular apoB secretion, i.e., a class iv defect discussed above. This mutation could be either in the apoB gene or some other product necessary for apoB secretion.

Though HBL is likely to be a heterogenous disease at the molecular level, our results in the homozygous HBL subjects studied are most consistent with a translational (class iii) defect, such as that leading to premature termination. This is suggested by the discordant results of a reduced quantity of mRNA and intracellular immunologically reactive apoB, in comparison to complete absence of apoB from the plasma. The abnormal protein produce could lead to translational modulation of mRNA stability with decreased mRNA levels and secondarily decreased translational rates. The structurally abnormal apoB would either not be secreted from the cell, or if secreted, would be very rapidly degraded. This aberration could result from either a point mutation or a very small insertion, deletion, or rearrangement. Undoubtedly, patients with class $i$ and class ii molecular variants will be detected in the future.

In conclusion, we have analyzed DNA, RNA, and protein from patients with homozygous HBL. A molecular defect at the translational level is consistent with our results and is distinct from the secretory defect found from evaluation of homozygous ABL. Additional studies will be necessary to further clarify the DNA sequence abnormalities in $\mathrm{HBL}$ as well as other syndromes where plasma apoB is decreased or absent. 

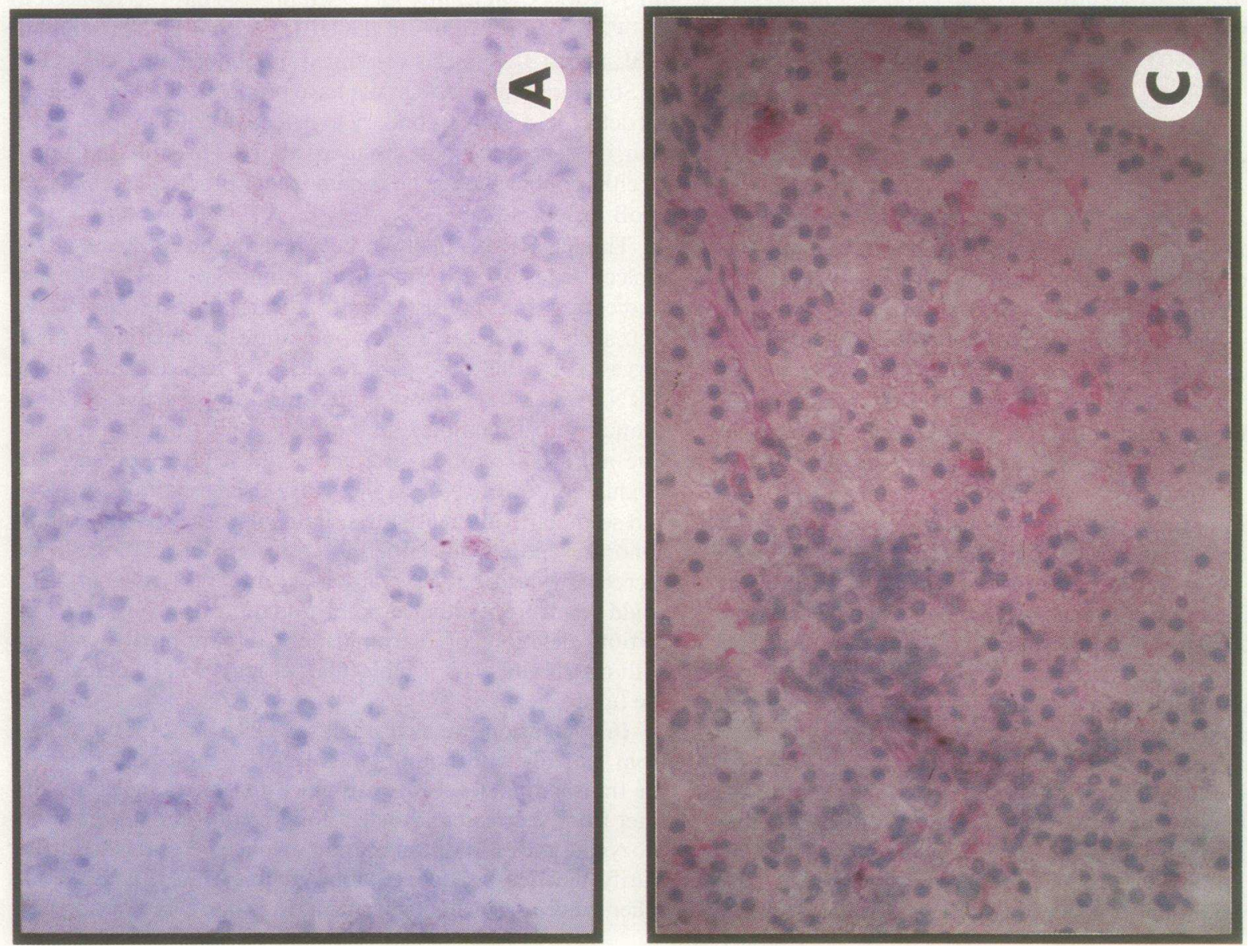

응 연 宅 है 글 边宫. ํํㅇㅎㅀ ब U ธ of 냉

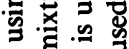
훙 党 궁 居 踏

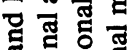
สํํㅇ

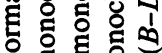
를 क 号总 สิ ส ธี ฝี తై 表告。 8 중

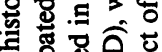

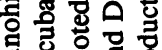
․ㅡ명 兒魚记 的影 承灵

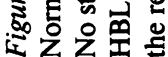




\section{Acknowledgments}

We thank Nancy Meglin and Chris Rall for their technical expertise and Joanie Gault for her secretarial assistance.

\section{References}

1. Herbert, P. N., G. Assman, A. M. Gotto, Jr. and D. S. Fredrickson. 1983. Familial lipoprotein deficiency: abetalipoproteinemia; hypobetalipoproteinemia and Tangier's disease. In The Metabolic Basis of Inherited Disease. J. B. Stanbury, J. B. Wyngaarden, D. S. Fredrickson, J. L. Goldstein, and M. S. Brown, editors. McGraw-Hill, Inc., New York. 605-607.

2. Mueller, D. P. R. 1982. Disorders of lipid absorption. In Clinics in Gastroenterology. J. T. Harries, editor. W. B. Saunders Co., Philadelphia. 11:119-141.

3. Avioli, L. V. 1969. Absorption and metabolism of Vitamin D3 in man. Am. J. Clin. Nutr. 22:437-446.

4. Mueller, D. P. R., and J. K. Lloyd. 1982. Effect of large oral doses of vitamin $\mathrm{E}$ on the neurological sequelae of patients with abetalipoproteinemia. Ann. NY Acad. Sci. 393:133-144.

5. Sobrevilla, L. A., M. L. Goodman, and C. A. Kane. 1964. Demyelinating central nervous system disease, vascular atrophy and acanthocytosis (Bassen-Kornzweig Syndrome). Am. J. Med. 37:821828.

6. Biemer, J. J., and R. E. McCammon. 1975. The genetic relationship of abetalipoproteinemia and hypobetalipoproteinemia: a report of the occurrence of both diseases within the same family. J. Lab. Clin. Med. 85:556-565.

7. Lackner, K. J., J. C. Monge, R. E. Gregg, J. M. Hoeg, T. J. Triche, S. W. Law, and H. B. Brewer, Jr. 1986. Analysis of the apolipoprotein $B$ gene and messenger ribonucleic acid in abetalipoproteinemia. J. Clin. Invest. 78:1707-1712.

8. Shaefer, E. J., W. H. Heaton, M. G. Wetzel, and H. B. Brewer, Jr. 1982. Plasma apoA-I absence associated with a marked reduction in HDL and premature coronary artery disease. Arteriosclerosis. 2:16-26.

9. Chirgwin, J. A., A. E. Przybyla, R. J. MacDonald, and W. J. Rutter. 1979. Isolation of biologically active ribonucleic acid from sources enriched in ribonuclease. Biochemistry. 18:5294-5299.

10. Lackner, K. J., S. W. Law, and H. B. Brewer, Jr. 1985. The human apolipoprotein A-II gene: complete nucleic acid sequence and genomic organization. Nucleic Acids Res. 13:4597-4608.

11. Law, S. W., S. M. Grant, K. Higuchi, A. Hospattankar, K. Lackner, N. Lee, and H. B. Brewer, Jr. 1986. Human liver apolipoprotein B-100 cDNA: complete nucleic acid and derived amino acid sequence. Proc. Natl. Acad. Sci. USA 83:8142-8146.

12. Protter, A. A., D. A. Hardman, J. W. Schilling, J. Miller, V. Appleby, G. C. Chen, S. W. Kirsher, G. McEnroe, and J. P. Kane. 1986. Isolation of a cDNA clone encoding the amino-terminal region of human apolipoprotein B. Proc. Natl. Acad. Sci. USA. 83:14671471.
13. Law, S. W., G. Gray, and H. B. Brewer, Jr. 1983. cDNA cloning of human apoA-I: amino acid sequence of preproapoA-I. Biochem. Biophy. Res. Commun. 112:257-264.

14. Law, S. W., and H. B. Brewer, Jr. 1984. Nucleotide sequence and the encoded amino acid of human apolipoprotein A-I mRNA. Proc. Natl. Acad. Sci. USA. 81:66-70.

15. Meinkoth, J., and G. Wahl. 1984. Hybridization of nucleic acids immobilized on solid supports. Anal. Biochem. 138:267-284.

16. Southern, E. M. 1975. Detection of specific sequences among DNA fragments separated by gel electrophoresis. J. Mol. Biol. 98:503-517.

17. Cordell, J. L., B. Falini, W. N. Erber, A. K. Ghosh, Z. Abdulaziz, S. MacDonald, K. A. F. Pulford, H. Stein, and D. Y. Mason. 1984. Immunoenzymatic labelling of monoclonal antibodies using immune complexes of alkaline phosphatase and monoclonal anti-alkaline phosphatase (APAAP complexes). J. Histochem. Cytochem. 32:219229.

18. Colton, T. 1974. Statistics in Medicine. Little, Brown, and Co., Boston. 11-62.

19. Blackhart, B. D., E. M. Ludwig, B. R. Pierolti, L. Caiati, M. A. Onasch, S. C. Wallis, L. Powell, R. Pease, T. J. Knott, M. L. Chu, R. W. Mahley, J. Scott, B. J. McCarthy, and B. Levy-Wilson. 1986. Structure of the apolipoprotein B gene. J. Biol. Chem. 261:1536415367.

20. Orkin, S. H., and H. H. Kazazian, Jr. 1984. The mutation and polymorphism of the human $\beta$-globin gene and its surrounding DNA. Annu. Rev. Genet. 18:131-171.

21. Antonarrakis, S. E., S. H. Orkin, T. C. Cheng, A. F. Scott, J. P. Sexton, and S. Trusko. 1984. $\beta$-Thalassemia in American blacks: novel mutations in the TATA box and the IVS-2 acceptor splice site. Proc. Natl. Acad. Sci. USA. 81:1154-1158.

22. Orkin, S. H., J. P. Sexton, T. C. Cheng, S. C. Goff, and P. J. V. Giardina. 1983. ATA box transcription mutation in $\beta$-thalassemia. Nucleic Acids Res. 11:4727-4734.

23. Orkin, S. H., S. E. Antonarakis, and H. H. Kazazian, Jr. 1984. Base substitution at position -88 in a $\beta$-thalassemic globin gene: further evidence for the role of distal promoter element ACACCC. J. Biol. Chem. 259:8679-8681.

24. Treisman, R., S. H. Orkin, and T. Maniatis. 1983. Specific transcription and RNA splicing defects in five cloned $\beta$-thalassemia genes. Nature (Lond.). 302:591-596.

25. Ley, T. J., N. P. Anagou, G. Pepe, and A. W. Nienhuis. 1982. RNA processing errors in patients with $\beta$-thalassemia. Proc. Natl. Acad. Sci. USA. 79:4775-4779.

26. Brawerman, G. 1987. Determinants of messenger RNA stability. Cell. 48:5-6.

27. Higgs, D. R., S. E. Y. Goodboum, J. Lamb, J. B. Clegg, and D. J. Weatherall, 1983. Alpha-thalassemia caused by a polyadenylation signal mutation. Nature (Lond.). 306:398-400.

28. Orkin, S. H., and S. C. Goff. 1981. Nonsense and frameshift mutations in $\beta$-thalassemia detected in cloned $\beta$ globin genes. $J$. Biol. Chem. 256:9782-9784. 